\title{
Evaluate Gluten-free Macaroni with Chia Seeds and Psyllium as Alternative Gluten to Celiac Diseases
}

\author{
Safaa M. Faid \\ Department of Home Economics, Faculty of Specific Education, Ain Shams \\ University, Cairo, Egypt \\ Email: safaafaid73@gmail.com
}

\section{ABSTRACT}

This investigation was accomplished to evaluate the raw materials like wheat flour $72 \%$ extract, chia seeds, soybean, yellow maize, and psyllium as alternative gluten to prepare different blends of macaroni gluten-free (GF) for celiac diseases (CD). Chemical composition, total dietary fiber fractions, minerals content, antioxidant capacity, and their activity were determined in raw materials. From the results, it could be noticed that the soybean and chia had the highest content from protein and total lipids; meanwhile, the psyllium had contained the highest amounts from crude fiber and dietary fibers fractions. Minerals content observed that the chia, soybean, and yellow maize have the highest amounts from the $\mathrm{Mg}, \mathrm{Na}, \mathrm{K}, \mathrm{P}$, and $\mathrm{F}$, respectively, than other raw materials. Moreover, soybean, yellow maize and chia had the highest contents in antioxidant capacity and activity.

The quality of the macaroni at different levels was evaluated through cooking tests (increase in weight and volume, and cooking loss), chemical composition (starch, amylose, and amylopectin), and color, also, sensory analysis by means of acceptance testing. The results reported that the glutenfree macaroni had higher nutritional value and superior technological characteristics. Sensory analysis results showed that pasta with $50 \%$ chia, $25 \%$ soybean, 20 maize and 5\% psyllium had higher rates of acceptability then came followed by $50 \%$ chia, $30 \%$ soybean, and 15 maize, $5 \%$ psyllium, and $50 \%$ chia, $35 \%$ soybean, and 10 maize, $5 \%$ psyllium. Meanwhile, the macaroni with the worst acceptance in the blend was the one with $50 \%$ chia flour, soybean $40 \%$, yellow maize 5\%, and psyllium 5\%, and also it was triggered the lowest acceptance with regards to color.

From the obvious results, it could be recommended that the macaroni which consists till $50 \%$ chia, 35\% soybean, $10 \%$ yellow maize, and 5\% psyllium was with increased in nutrition value and color.

Keywords: Macaroni, cooking loss, amylase, amylopectin 


\section{INTRODUCTION}

Gluten-sensitive enteropathy is an inflammatory disease which refers to celiac disease (CD). It could have caused the ingestion of gluten which affecting $1 \%$ of the population worldwide (Catassi and Yachha, 2009).

The special advantage of CD is flattening of the intestinal villi, which decreases the surface region and out comes in alimentary malabsorption. Evermore people follow a gluten-free diet, because there has been an increase in the number of individuals diagnosed with the disease and for this reason it has been explained that gluten intake may be due to gastrointestinal symptoms in some persons without CD (Biesiekierski et al., 2011) or because of false beliefs. This has led to elevate gluten-free bakery products in the supermarket at recent years (Cureton and Fasano, 2009).

The persons with CD troubles still have desorder finding GF products for the reason that of expensive for price, and poor sensory characteristics. These agents are accountable for hampering the GF diet system and for lack of satisfaction (Do Nascimento et al., 2013).

The process developing of GF products stays a technological challenge may be caused to the gluten in different cereal-based products, particularly in bread and pasta making. (Capriles et al., 2015),

Chia seeds (Salvia hispanica L.) had contained healthy $\omega$ - 3-fatty acids, and high nutrition compositions. In addition, the seeds had contained high amounts from polyphenols and natural antioxidants, such as caffeic acid, rosmarinic acid, myricetin, quercetin, and others (Hrnčič et al., 2020).

The corn color is mainly due to the presence of natural antioxidant likes phenolic acids, carotenoids, and flavonoids. Pigments are generally mostly concentrated in the thick pericarp or in the aleurone layers of kernels, and also in corn cobs (Paulsmeyer et al., 2017).

Soybean (Glycine max (L.) had contained high amounts of protein and fat ranged $35-42 \%$ and $16-27 \%$, respectively. This led to the soybean is one of the valuable and more cultivated crops (Kumar et al., 2006).

Psyllium seed consists of Plantago afra L. (Plantago psyllium L.). Husk and seeds is however commonly also referred to as psyllium. psyllium husk are obtained by milling the seed to remove the hulls (Wärnberg et al., 2009).

Psyllium was chosen because it is stable at various $\mathrm{pH}$ levels and temperatures, being similar to gluten in food. Moreover, psyllium can be as alternative for fat or thickening factor. Also, psyllium and gluten free flour have possibility in novel ingredients for patients with celiac disease (Zandonadi et al., 2009).

This study aimed to elaborate gluten-free macaroni with the raw materials ( chia seeds, soybean, yellow maize, and psyllium) to prepare macaroni with 
high technological characteristics and nutrition value similar to those produced with wheat flour.

\section{MATERIALS AND METHODS Materials:}

Wheat (Treatucm astivum L.), Chia seeds (Salvia hispanica L.), Yellow maize (Zea mays L.), and also, psyllium husk (Plantago ovate), were obtained from the Field Crops Research Institute, Agricultural Research Center, Egypt Methods:

\section{Determination of chemical composition of raw materials}

Chemical composition as protein, fat, crude fibers and ash content were determined in raw materials according to the methods of AOAC (2010) and also, total carbohydrates were determined by differences. Total dietary fibers, soluble and insoluble dietary fibers were determined in raw materials according to Prosky et al. (1988).

\section{Determination of minerals content:}

Macro elements (calcium and magnesium) and Microelements (iron, zinc, manganese, selenium, aluminum and copper) of raw materials were determined according to the method of the AOAC. (2010), using Atomic Absorption Spectrophotometer (Perkin Elmer, Model 3300, Germany). Phosphorus was determined by spectrophotometer using molybdovan date method according to the AOAC. (2010), while sodium and potassium contents were determined by Flame Photometer (CORNING 400, serial No. 4889.UK).

\section{Macaroni preparation processing:}

The ingredients preparation processing macaroni are reported in Table (1). The ingredients were mixed in Hobert mixture at high speed until uniformly (10 min.) and the required amount of water was added. Macaroni was processed using a Demaco (De Francise Machine Corporation), it was dried at $60^{\circ} \mathrm{C}$ for $24 \mathrm{~h}$ and the relative humidity was from 75 to $85 \%$ according to the method described by Dexter et al. , (1994).

Table (1): Ingredient of macaroni blends

\begin{tabular}{|c|c|c|c|c|c|}
\hline Blends & Wheat & Chia & Soybean & $\begin{array}{c}\text { Yellow } \\
\text { maize }\end{array}$ & Psullium \\
\hline Control & 100 & --- & --- & -- & --- \\
\hline Blend 1 & -- & 50 & 25 & 20 & 5 \\
\hline Blend 2 & --- & 50 & 30 & 15 & 5 \\
\hline Blend 3 & --- & 50 & 35 & 10 & 5 \\
\hline Blend 4 & --- & 50 & 40 & 5 & 5 \\
\hline
\end{tabular}




\section{Determination of ABTS, DPPH and FRAP radical solutions}

The ABTS was determined according to Re et al., (1999). The working solution absorbance was $0.75-0.80$ at $734 \mathrm{~nm}$.

The DPPH was prepared and determined according to Brand- Williams et al. (1995); its absorbance was $0.75-0.80$ at $525 \mathrm{~nm}$.

The FRAP was prepared and determined as described by Benzie and Strain (1996).

\section{Estimation of antioxidant activity from raw materials extract}

The total phenolic content in the different samples was measured using the method of Qawasmeh et al. ,(2012) with Folin-Ciocalteu reagent. Gallic acid was used as standard $(1 \mathrm{mg} / \mathrm{ml})$ and the results were expressed as gallic acid equivalents (GAE $\mathrm{mg} / \mathrm{g}$ of dry weight).

The total flavonoids content was determined by the method of Eghdami and Sadeghi (2010). The absorbance was measured against a blank solution at $510 \mathrm{~nm}$ and the total flavonoids content was expressed in terms of milligrams of quercetin equivalent per gram dry weight ( $\mathrm{mg} \mathrm{QE} / \mathrm{g}$ of dry weight).

\section{Cooking properties of macaroni}

The changes in volume, weight and cooking loss were determined according to Bilgiçli et al. ,(2011). Ten g of macaroni control and its blends were cooked for $18 \mathrm{~min}$ in $300 \mathrm{ml}$ of distilled water. To determine the volume increase, uncooked and cooked macaroni blends were put into a graduated cylinder with the specific amount of distilled water, the increase in water level was measured. The volume increase was calculated as the percentage difference in the volume of uncooked and cooked macaroni divided by the volume of uncooked macaroni. The weight increase was determined as the percentage difference in weight of uncooked and cooked (after draining) macaroni divided by the weight of uncooked macaroni. Cooking loss, the weight of total solids expressed as a percentage was determined by drying the cooking water to constant weight at $100^{\circ} \mathrm{C}$.

\section{Determination of starch in macaroni before and after cooking:}

Starch was determined by the method of dispersal in $\mathrm{CaCl} 2$, followed by iodine spectrophotometry (Idris, 2001). The blue color intensity was measured at $610 \mathrm{~nm}$ using WPA S101 spectrophotometer.

\section{Estimation of amylose content in macaroni before and after cooking:}

A rapid colorimetric method described by William et al. (1975) was used for estimating the amylose content. The volume was diluted to $50 \mathrm{ml}$ and the absorbance of blue colour was measured at $625 \mathrm{~nm}$ after 5 minutes. 


\section{Determination of amylopectin in macaroni before and after cooking:}

The amylopectin content of starch was calculated by difference. Amylose content was calculated as percentage (\%) from the starch. Then amylose percent was subtracted from 100 to obtain amylopectin content of starch (Idris , 2001) .

\section{Color measurement of macaroni blends}

Color measurements were performed using Minolta chroma meter CR400 (Minolta, Osaka, Japan). The numerical values of the color were expressed as lightness $\left(L^{*}\right.$, light-dark), redness $\left(a^{*}, \pm\right.$ red-green $)$ and yellowness $\left(b^{*}\right.$, tyellow blue) according to Francis (1998).

\section{Sensory evaluation of macaroni blends:}

Samples of the variable macaroni were cooked to optimum cooking time (10 minute for macaroni) and with optimum boiling water ( 1 liter/100g sample). Then rinsed and drained off. A panel of twenty experienced panelists were chosen to judge the quality of the macaroni (external appearance, firmness, stickiness, color, aroma, taste and general acceptability)-using the scoring test of 5 points described by Bahnassey and khan (1986).

\section{Statistical analysis:}

The data obtained were analyzed using Statistical Package for Social Sciences program (SPSS) for Windows, (version 13 SPSS Inc., Chicago. USA). The results were expressed as mean $\pm \mathrm{SD}$. Tested for significance using oneway analysis of variance "ANOVA" according to (Armitage and Berry 1987).

\section{RESULTS AND DISCUSSION}

\section{Chemical composition of raw materials}

Chemical composition and total fiber fractions were estimated in raw materials (wheat flour, chia seeds, soybean, yellow maize, and psyllium and the findings are illustrated in Table (2). From the results, it could be noticed that the soybean had contained rich amounts from protein and total lipids by 36.27 and $23.51 \%$, these results confirmed by Kumar et al., 2006). Followed by chia seeds was 24.43 and $20.34 \%$ in protein and fat, respectively. Ixtaina et al. (2011) who found that the chia seed had contained high amounts from protein, fats, carbohydrates, high dietary fiber and ash were ranged $15-25 \%, 20-30 \%$, $26-41 \%, 18-30 \%$, and $4-5 \%$, respectively, in addition minerals, vitamins, and dry matter were 90-93 and high source of natural antioxidants.

Moreover, psyllium, chia seeds, and soybean were the highest in crude fiber by $60.66,11.36$, and $8.72 \%$, and ash content was $23.33,9.62$, and $5.29 \%$, 
respectively. Meanwhile, wheat flour and yellow maize were the highest in total carbohydrates by 84.16 and $83.01 \%$.

The results in the same table showed that the psyllium was the highest in total dietary fiber $(82.26 \%)$ followed by soybean and chia seeds were 36.20 and $28.35 \%$, respectively. As well, the yellow maize lower in dietary fiber was $14.72 \%$ and wheat flour was the lowest than other raw materials such as psyllium husk as a dietary fiber which have been utilized extensively for food recipes and in produce food (Verma and Mogra, 2015). In soybeans had concentrated levels of TDF, IDF and SDF were 35.9 $\pm 4.6,26.2 \pm 1.9$ and $9.7 \pm$ $3.3 \mathrm{~g} / 100 \mathrm{~g}$, respectively (Písarríková and Zralý, 2010). The chia seeds are also a significant source of protein (19-23\%) and dietary fiber (18-30\%), vitamin and mineral (Coelho and Salas-Mellado, 2015). The total dietary fiber content of wheat ranges from 9 to about 20\% (dry weight basis) and is composed of both insoluble and soluble fractions (Gartaula et al., 2018).

Table (2): Chemical composition of raw materials

\begin{tabular}{|c|c|c|c|c|c|}
\hline $\begin{array}{c}\text { Chemical } \\
\text { composition }\end{array}$ & $\begin{array}{c}\text { Wheat } \\
\text { flour }\end{array}$ & $\begin{array}{c}\text { Chia } \\
\text { seeds }\end{array}$ & Soybean & $\begin{array}{c}\text { Yellow } \\
\text { maize }\end{array}$ & Psyllium \\
\hline Crude protein \% & 12.45 & 24.43 & 36.27 & 8.49 & 1.33 \\
& \pm 0.91 & \pm 1.92 & \pm 3.61 & \pm 0.97 & \pm 0.01 \\
\hline Crude fiber\% & 0.71 & 11.36 & 8.72 & 4.14 & 60.66 \\
& \pm 0.03 & \pm 0.91 & \pm 1.04 & \pm 0.16 & \pm 0.02 \\
\hline Total lipids\% & 2.07 & 20.34 & 23.51 & 3.16 & 2.7 \\
& \pm 0.04 & \pm 1.86 & \pm 2.15 & \pm 0.06 & \pm 1.28 \\
\hline Ash content\% & 0.61 & 9.62 & 5.29 & 1.20 & 23.33 \\
& \pm 0.02 & \pm 0.02 & \pm 0.06 & \pm 0.09 & \pm 4.36 \\
\hline Total carbohydrates & 84.16 & 34.25 & 26.21 & 83.01 & 11.98 \\
$\%$ & \pm 3.19 & \pm 1.37 & \pm 2.07 & \pm 4.28 & \pm 0.78 \\
\hline Total dietary fiber \% & 8.24 & 28.35 & 36.20 & 14.72 & 82.26 \\
(TDF) & \pm 1.25 & \pm 1.26 & \pm 3.28 & \pm 1.05 & \pm 6.28 \\
\hline Insoluble dietary & 6.10 & 18.70 & 24.13 & 10.16 & 54.84 \\
fiber\% (IDF) & \pm 0.92 & $\pm 1,21$ & \pm 1.94 & \pm 0.61 & \pm 4.27 \\
\hline Soluble dietary fiber & 2.09 & 9.35 & 12.06 & 4.56 & 27.42 \\
$\%$ (SDF) & \pm 0.04 & \pm 0.15 & \pm 1.35 & \pm 0.08 & \pm 2.36 \\
\hline
\end{tabular}

Values are mean and SD $(n=3)$.

\section{Minerals content of raw materials}

Minerals content as $\mathrm{Mg}, \mathrm{Na}, \mathrm{K}, \mathrm{Zn}, \mathrm{P}, \mathrm{Fe}, \mathrm{Ca}$, and $\mathrm{Cu}$ were determined in raw material and the results are in Table (3). The results observed that the chia seeds the highest content in the minerals by 245.0, 120.0, 410.0, 4.0, 450.0, $9.0,218.0$, and $3.0 \mathrm{mg} / 100 \mathrm{~g}$ dry weight respectively, these results confirmed 
by Levent (2017) who found that the chia seed had contented of $\mathrm{Ca}, \mathrm{P}, \mathrm{K}, \mathrm{Mg}$, $\mathrm{Fe}$, and $\mathrm{Zn}$ increased in noodles containing chia seed. Followed by soybean had contained 110.0, 94.0, 650.0, 3.0, 385.0, 6.0, 140.0 and $4.0 \mathrm{mg} / 100 \mathrm{~g}$ and yellow maize was $90.0,85.0,215.0,3.0,310.0,5.0,200.0$ and $3.0 \mathrm{mg} / 100 \mathrm{~g}$. Whilst, psyllium and wheat flour were lower than other raw materials. The minerals content level in the different plants is dependent on environmental and various agents through agronomic practices ( Devi et al., 2013).

Table (3): Minerals content of raw materials on dry weight basis $\mathbf{m g} / \mathbf{1 0 0 g}$

\begin{tabular}{|c|c|c|c|c|c|}
\hline $\begin{array}{c}\text { Chemical } \\
\text { composition }\end{array}$ & Wheat flour & Chia seeds & Soybean & $\begin{array}{c}\text { Yellow } \\
\text { maize }\end{array}$ & Psyllium \\
\hline Magnesium & $12.94 \pm 0.11$ & $245.0 \pm 2.47$ & $110.00 \pm 3.49$ & $95.00 \pm 2.36$ & $53.00 \pm 0.94$ \\
\hline Sodium & $20.58 \pm 0.43$ & $120.0 \pm 1.25$ & $94.00 \pm 3.14$ & $85.00 \pm 3.15$ & $65.00 \pm 0.83$ \\
\hline Potassium & $140.21 \pm 8.26$ & $410.0 \pm 3.49$ & $650.00 \pm 5.61$ & $215.00 \pm 1.49$ & $115.00 \pm 1.04$ \\
\hline Zinc & $0.48 \pm 0.04$ & $4.00 \pm 0.01$ & $3.00 \pm 0.04$ & $3.00 \pm 0.02$ & $1.00 \pm 0.00$ \\
\hline Phosphorus & $210.00 \pm 5.13$ & $450.0 \pm 4.21$ & $385.00 \pm 2.46$ & $310.00 \pm 2.58$ & $185.00 \pm 1.39$ \\
\hline Iron & $6.75 \pm 0.08$ & $9.00 \pm 0.04$ & $6.00 \pm 0.04$ & $5.00 \pm 0.07$ & $2.00 \pm 0.01$ \\
\hline Calcium & $18.25 \pm 0.18$ & $218.00 \pm 1.28$ & $140.00 \pm 1.46$ & $200.00 \pm 2.05$ & $40.00 \pm 0.57$ \\
\hline Copper & $1.75 \pm 0.01$ & $3.00 \pm 0.02$ & $4.00 \pm 0.01$ & $3.00 \pm 0.01$ & $1.00 \pm 0.00$ \\
\hline
\end{tabular}

Values are mean and SD $(\mathrm{n}=3)$.

\section{Antioxidant capacity and activity of raw materials}

Antioxidant capacity was determined in raw materials and the results are reported in Table (4). From the results, it could be noticed that the soybean the highest in antioxidant capacity as ABTS, DPPH and FRAP were found 5.15, 3.64 and $7.50 \mathrm{Mmol}$ (Trolox equivalent antioxidant capacity) $\mathrm{TEACg}^{-1}$, respectively. DPPH is a radical that variations into a steady compound by interacting with an antioxidant. Therefore the possibility of soybean accession to scavenge DPPH radicals indicating that it is an electron donor which can react with free radicals to transform them to more stable products and thereby terminate radical chain reactions. Followed by yellow maize was 3.89, 3.81, and 5.12 $\mathrm{Mmol} \mathrm{TEACg}^{-1}$ and chia seeds was 3.21, 2.43 and 3.39 $\mathrm{Mmol} \mathrm{TEACg}^{-}$ ${ }^{1}$, respectively. Sargi et al., (2013) found that chia seeds which capable inhibiting the activity of ABTS cation radicals and also chia seeds exhibit the capacity to scavenge synthetic DPPH radicals and decrease iron ions. In addition, Khampas et al,. (2013) who found the total antioxidant capacity was significantly correlated with TEAC, DPPH, FRAP, and TPC. TPC had positive and significant correlations with TEAC, FRAP, and DPPH. Positive and significant correlations between DPPH with TEAC and FRAP were observed, whereas FRAP had a close association with TEAC. This information was used for corn to development of healthy food products and pharmaceutical 
industries. Meanwhile psyllium and wheat flour were the lowest in antioxidant capacity. Patel et al. (2016) observed that the DPPH scavenging activity and ABTS for antioxidant activity is a percent inhibition of ABTS + , of the psyllium plant. The maximum activity was found in the seed extract, followed by leaf and husk extracts. Therefore, the natural antioxidant present in the psyllium seeds may be scavenging the free radical due to their electron donor ability (Fan et al., 2014).

The results from the same table showed that the total phenolic content and total flavonoids compounds were the highest in soybean followed by yellow maize, chia seeds and psyllium hull. Meanwhile, the wheat flour was the lowest in the total phenolic content and total flavonoids compounds. These results confirmed with Mujić et al. (2011) who found that the soybeans (Glycine $\max (\mathrm{L}$. ) Merr) is a legume that is universally consumed. A soybean is a complex food matrix containing a wide array of bioactive phytochemicals like isoflavones, and total phenolics content.

For this reason, the chia seed is rich in vitro antioxidant activity (Marineli et al., 2014 and Porras-Loaiza et al., 2014). Moreover, corn (Zea mays L.) has colors like white, yellow, orange, purple, and black. These pigments of corn are rich in phytochemicals and many secondary metabolites such as phenolic compounds, carotenoids, and flavonoids (Žilić et al., 2012). As well as, Plantago ovata, commonly called psyllium, is known to be a rich source of phytochemicals such as phenols and flavonoids compounds (Yasin et al., 2020).

Table (4): Antioxidants of raw materials

\begin{tabular}{|c|c|c|c|c|c|}
\hline Antioxidants & $\begin{array}{c}\text { Wheat } \\
\text { flour }\end{array}$ & $\begin{array}{c}\text { Chia } \\
\text { seeds }\end{array}$ & Soybean & $\begin{array}{c}\text { Yellow } \\
\text { maize }\end{array}$ & Psyllium \\
\hline ABTS & 0.51 & 3.21 & 5.15 & 3.89 & 2.52 \\
Mmol TEACg $^{-1}$ & \pm 0.02 & \pm 0.02 & \pm 0.12 & \pm 0.16 & \pm 0.25 \\
\hline DPPH & 0.72 & 2.43 & 3.64 & 3.81 & 1.73 \\
Mmol TEACg $^{-1}$ & \pm 0.01 & \pm 0.01 & \pm 0.03 & \pm 0.17 & \pm 0.14 \\
\hline FRAP & 0.10 & 3.39 & 7.50 & 5.12 & 1.65 \\
Mmol TEACg & \pm 0.00 & \pm 0.02 & \pm 0.14 & \pm 0.00 & \pm 0.01 \\
\hline Total phenolic acids & 0.50 & 0.98 & 3.51 & 2.01 & 0.72 \\
mg GAE /g of dry & \pm 0.01 & \pm 0.04 & \pm 0.02 & \pm 0.01 & \pm 0.04 \\
weight & & & & & \\
\hline Total flavonoid & $0 . .20$ & 0.53 & 1.32 & 0.75 & 0.24 \\
mg QE /g dry weight & \pm 0.01 & \pm 0.01 & \pm 0.01 & \pm 0.09 & $\pm 0,02$ \\
\hline
\end{tabular}

Values are mean and SD $(n=3)$. 


\section{Cooking characterization of the macaroni}

The increases of weight and volume and also cooking losses were evaluated in macaroni different blends and the results are reported in Table (5). The results illustrated that the volume and weight were elevated in macaroni made from wheat flour $72 \%$ extract by 140.25 and $164.28 \%$ to 230.59 and $246.92 \%$ in blends made from chia seeds $50 \%$, soybean $40 \%$, yellow maize $5.0 \%$ and psyllium $5 \%$ as alternative gluten. These increases in volume and weight may be due to the chia seeds and soybean had contained high amounts from dietary fiber which absorption the water. Moreover, the psyllium was the highest in crude fiber and dietary fibers therefore the function properties of it were as an alternative to gluten and keeping of water. Capitani et al., (2012) stated that even though the soluble fiber (SF) content is low, the mucilage fulfills the functional property of water retention.

The results from the cooking losses in the macaroni different blends are reported in the same table. The results indicated that the macaroni made from wheat flour $72 \%$ extract give the best quality of cooking loss $(6.21 \%)$. Whilst, the different blend observed that when increase added soybean in macaroni blends 2, 3, 4 and 5 were $7.65,8.08,9.23$ and $11.12 \%$, respectively. These results confirmed with Hummel (1966) classified pasta according to the loss of solids: up to $6 \%$ is characteristic of pasta made from the wheat of very good quality, up to $8 \%$ of average quality, and values equal to or greater than $10 \%$ are low-quality pasta. The added chia flour improved the quality of the pasta by reducing the loss of solids. The result can be attributed to the composition of the chia grain, which rich in protein and this causes the retention of amylose during cooking (Chillo et al., 2008 and Zhao et al., 2005), upon adding flours of legumes (bean and chickpea) to pasta, observed an increase in the loss of solids during cooking.

Table (5): Percentage of cooking test parameters of macaroni blends

\begin{tabular}{|c|c|c|c|}
\hline Blends & Volume increase & Weight increase & Cooking loss \\
\hline Control & $140.25 \pm 2.35 \mathrm{~d}$ & $164.28 \pm 1.97 \mathrm{~d}$ & $6.21 \pm 0.18 \mathrm{~d}$ \\
\hline Blend 1 & $185.65 \pm 2.37 \mathrm{c}$ & $183.39 \pm 2.28 \mathrm{c}$ & $7.65 \pm 1.25 \mathrm{c}$ \\
\hline Blend 2 & $200.14 \pm 3.21 \mathrm{~b}$ & $215.19 \pm 2.68 \mathrm{ab}$ & $8.08 \pm 1.39 \mathrm{~b}$ \\
\hline Blend 3 & $212.38 \pm 3.48 \mathrm{ab}$ & $230.17 \pm 3.01 \mathrm{ab}$ & $9,23 \pm 0.98 \mathrm{ab}$ \\
\hline Blend 4 & $230.59 \pm 3.86 \mathrm{a}$ & $246.92 \pm 2.83 \mathrm{a}$ & $11.12 \pm 0.68 \mathrm{a}$ \\
\hline
\end{tabular}

Values are mean and SD $(n=3)$; where: Mean values in the same column and with the different letter are significantly different at 0.05 levels.

\section{Chemical composition of macaroni before and after cooking:}

Chemical composition as starch, amylose and amylopectin content were determined in macaroni before and after cooking and the findings are tabulated 
in Table (6). The macaroni before cooking were decreased in starch, amylase and amylopectin when the soybean powder was increased in the different blends. Whilst, after cooking the macaroni blends were 25, 30, 35 and $40 \%$ soybean powder were decreased in starch by $20.20,17.28,16.47$ and $14.52 \%$, respectively, compared with control macaroni was found $25.48 \%$. Moreover amylase and amylopectin were reduced by $23.03,21.82,19.87$ and $18.32 \%$, respectively; in amylase than control macaroni was $24.27 \%$. In addition, amylopectin was decreased by $24.81,23.97,22.77$ and $21.51 \%$, respectively; than control macaroni was $25.50 \%$. These decreases may be due to the blend macaroni had contained different levels from the raw materials which contained high amounts from dietary fiber and natural antioxidants. Moreover, the elevating of celiac disease (CD) and gluten-related troubles give to increase consumer request for gluten-free products. Starch plays an significant role in the bakery products and has an even more become better role in gluten-free products. Starch is used in food ingredient to get better properties gluten-free products, such as the specific volume, color, crumb structure, and texture.

Regular pasta, which is made from semolina, is not an ideal source of dietary fiber as most have been removed during the milling of the grain. There is good evidence that regular consumption of wholegrain cereals offers a reduced risk of certain diseases like type 2 diabetes and cardiovascular disease (Zong et al., 2014). Despite this knowledge, the daily intake of dietary fiber falls well short of daily recommendations, with more than $90 \%$ of the population of the USA, for example, not meeting target levels (Jones, 2014).

Table (6): Starch, amylose and amylopectin content of macaroni before and after cooking.

\begin{tabular}{|c|c|c|c|c|c|c|}
\hline \multirow{2}{*}{ Blends } & \multicolumn{2}{|c|}{ Starch \% } & \multicolumn{2}{c|}{ Amylose \% } & \multicolumn{2}{c|}{ Amylopectin \% } \\
\cline { 2 - 7 } & $\begin{array}{c}\text { Before } \\
\text { cooking }\end{array}$ & $\begin{array}{c}\text { After } \\
\text { cooking }\end{array}$ & $\begin{array}{c}\text { Before } \\
\text { cooking }\end{array}$ & $\begin{array}{c}\text { After } \\
\text { cooking }\end{array}$ & $\begin{array}{c}\text { Before } \\
\text { cooking }\end{array}$ & $\begin{array}{c}\text { After } \\
\text { cooking }\end{array}$ \\
\hline Control & 70.12 & 52.25 & 24.76 & 18.75 & 44.67 & 33.28 \\
& $\pm 1.24^{\mathrm{a}}$ & $\pm 1.26^{\mathrm{a}}$ & $\pm 0.14^{\mathrm{a}}$ & $\pm 0.24^{\mathrm{a}}$ & $\pm 0.51^{\mathrm{a}}$ & $\pm 0.21^{\mathrm{a}}$ \\
\hline Blend 1 & 65.61 & 52.36 & 21.45 & 16.51 & 39.75 & 29.89 \\
& $\pm 1.56^{\mathrm{ab}}$ & $\pm 1.28^{\mathrm{ab}}$ & $\pm 0.18^{\mathrm{ab}}$ & $\pm 0.27^{\mathrm{ab}}$ & $\pm 0.36^{\mathrm{ab}}$ & $\pm 0.35^{\mathrm{ab}}$ \\
\hline Blend 2 & 60.24 & 45.83 & 20.86 & 15.53 & 37.67 & 28.341 \\
& $\pm 1.58 \mathrm{ab}$ & $\pm 1.67^{\mathrm{ab}}$ & $\pm 0.12^{\mathrm{ab}}$ & $\pm 0.19^{\mathrm{ab}}$ & $\pm 0.41^{\mathrm{ab}}$ & $\pm 0.29^{\mathrm{ab}}$ \\
\hline Blend 3 & 54.63 & 42.63 & 19.67 & 14.76 & 35.58 & 26.78 \\
& $\pm 1.23^{\mathrm{b}}$ & $\pm 0.98^{\mathrm{b}}$ & $\pm 0.19^{\mathrm{b}}$ & $\pm 0.12^{\mathrm{b}}$ & $\pm 0.38^{\mathrm{b}}$ & $\pm 0.31^{\mathrm{b}}$ \\
\hline Blend 4 & 49.47 & 41.29 & 18.12 & 14.10 & 33.56 & 25.34 \\
& $\pm 0.98^{\mathrm{c}}$ & $\pm 0.75^{\mathrm{c}}$ & $\pm 0.11^{\mathrm{c}}$ & $\pm 0.11^{\mathrm{c}}$ & $\pm 0.26^{\mathrm{c}}$ & $\pm 0.21^{\mathrm{c}}$ \\
\hline
\end{tabular}

Values are mean and SD $(n=3)$; where: Mean values in the same with the letter are significantly different at 0.05 levels. 


\section{Color analysis of different blends macaroni}

Greater intensity of the yellow color is a highly desirable feature in pasta products because this is one of the most influential visual appeals in the acceptance of pasta (Chang and Flores, 2004).

Table (7) showed that the color values of the macaroni blend gluten-free made with chia seeds, soybean, yellow maize, and psyllium as alternative gluten at different levels. The color of the blends 1, 2, 3, and 4 were darker than the standard, which was shown by lower luminance values and a greater tendency to red (higher $a^{*}$ values) and blue (lower $b^{*}$ values), indicating that the dark pigmentation of the chia flour and increasing added of soybean was significantly influenced the color of the macaroni. These data corroborate the study by Bordin and Roque-Specht (2012) on pastas with added soybean fiber. The control pasta differed statistically from others featuring greater intensity of the yellow color ( $b^{*}$ value), favoring acceptability, which was expected because the added chia flour made the pasta darker.

Table (7). Color analysis of different blends macaroni

\begin{tabular}{|c|c|c|c|}
\hline $\begin{array}{c}\text { Pan bread } \\
\text { formulae }\end{array}$ & $L^{*}$ & $a^{*}$ & $b^{*}$ \\
\hline Control wheat & $65.5^{\mathrm{a}} \pm 1.68$ & $1.2^{\mathrm{e}} \pm 0.01$ & $37.4^{\mathrm{a}} \pm 1.25$ \\
\hline Blend 1 & $59.4^{\mathrm{b}} \pm 1.76$ & $2.1^{\mathrm{d}} \pm 0.01$ & $32.5^{\mathrm{b}} \pm 1.36$ \\
\hline Blend 2 & $53.1^{\mathrm{c}} \pm 1.23$ & $3.1^{\mathrm{c}} \pm 0.02$ & $34.7^{\mathrm{b}} \pm 1.54$ \\
\hline Blend 3 & $51.9^{\mathrm{c}} \pm 1.38$ & $3.7^{\mathrm{c}} \pm 0.02$ & $29.3^{\mathrm{c}} \pm 0.98$ \\
\hline Blend 4 & $46.6^{\mathrm{d}} \pm 1.15$ & $4.1^{\mathrm{b}} \pm 0.03$ & $26.1^{\mathrm{c}} \pm 0.73$ \\
\hline
\end{tabular}

Values are means $\pm \mathrm{SD}(\mathrm{n}=3)$. Means followed by different letters in the same column are, significantly different $(\mathrm{P} \leq 0.05)$

\section{Sensory properties of different blends macaroni}

The results of the sensory analysis are shown in Table (8). It can be observed that the macaroni with better acceptance by the tasters in the blend (1) was the one containing $50 \%$ of chia flour, soybean $25 \%$, yellow maize $20 \%$, and psyllium 5\%, and which it was the most accepted with respect to the aroma, color, stickiness and firmness attribute, followed by the macaroni blend (2) with $30 \%$ soybean and 15 maize and blend (3) was contained 35\% soybean and $10 \%$ yellow maize. Meanwhile, the macaroni with the worst acceptance in the blend (4) was the one with $50 \%$ chia flour, soybean $40 \%$, yellow maize $5 \%$, and psyllium 5\% and also it was triggered the lowest acceptance with regards to color. This fact can be explained by the very dark color of the pasta to which consumers are not accustomed. Similar results were also reported by Bordin and Roque-Specht (2012), while developing pastas with different concentrations of soybean fiber, of which the pasta with $6 \%$ fiber was preferred in terms of flavor. 
Table (8): Sensory properties of different macaroni:

\begin{tabular}{|c|c|c|c|c|c|c|c|}
\hline Blends & $\begin{array}{l}\text { External } \\
\text { appearance }\end{array}$ & Firmness & Stickiness & Color & Aroma & Taste & $\begin{array}{l}\text { General } \\
\text { acceptability }\end{array}$ \\
\hline Control & $\begin{array}{l}5.00 \\
\pm 0.03^{\mathrm{a}}\end{array}$ & $\begin{array}{l}4.70 \\
\pm 0.02^{a}\end{array}$ & \begin{tabular}{|l}
4.30 \\
$\pm 0.04^{\mathrm{a}}$
\end{tabular} & \begin{tabular}{|l}
4.70 \\
$\pm 0.02^{a}$
\end{tabular} & \begin{tabular}{|l}
4.50 \\
$\pm 0.04^{2 \mathrm{a}}$
\end{tabular} & \begin{tabular}{|l}
4.50 \\
$\pm 0.03^{a}$
\end{tabular} & $\begin{array}{l}4.62 \\
\pm 0.02^{\text {a }}\end{array}$ \\
\hline $\begin{array}{c}\text { Blend } \\
1\end{array}$ & $\begin{array}{l}4.05 \\
\pm 0.03^{\mathrm{ab}}\end{array}$ & $\begin{array}{l}4.10 \\
\pm 0.02^{b}\end{array}$ & \begin{tabular}{|l}
4.05 \\
$\pm 0.04 \mathrm{a}$
\end{tabular} & $\begin{array}{l}4.50 \\
\pm 0.03^{b}\end{array}$ & $\begin{array}{l}4.00 \\
\pm 0.02^{\mathrm{ab}}\end{array}$ & $\begin{array}{l}4.25 \\
\pm 0.02^{b}\end{array}$ & $\begin{array}{l}4.16 \\
\pm 0.02^{b}\end{array}$ \\
\hline Blend 2 & \begin{tabular}{|l}
3.75 \\
$\pm 0.02^{\mathrm{ab}}$
\end{tabular} & \begin{tabular}{|l}
3.75 \\
$\pm 0.01^{\text {bc }}$
\end{tabular} & \begin{tabular}{|l}
3.75 \\
$\pm 0.02^{\mathrm{ab}}$
\end{tabular} & $\begin{array}{l}4.00 \\
\pm 0.02^{\text {bc }}\end{array}$ & \begin{tabular}{|l}
3.75 \\
$\pm 0.01^{b}$
\end{tabular} & $\begin{array}{l}3.75 \\
\pm 0.02^{\mathrm{bc}}\end{array}$ & \begin{tabular}{|l|}
3.79 \\
$\pm 0.02^{\text {bc }}$
\end{tabular} \\
\hline Blend 3 & $\begin{array}{l}3.50 \\
\pm 0.01^{b}\end{array}$ & \begin{tabular}{|l}
3.25 \\
$\pm 0.01^{\mathrm{bc}}$
\end{tabular} & \begin{tabular}{|l}
3.25 \\
$\pm 0.01^{b}$
\end{tabular} & \begin{tabular}{|l}
3.50 \\
$\pm 0.02^{c}$
\end{tabular} & \begin{tabular}{|l|}
3.50 \\
$\pm 0.01^{c}$
\end{tabular} & \begin{tabular}{|l}
3.25 \\
$\pm 0.01^{\mathrm{c}}$
\end{tabular} & \begin{tabular}{|l}
3.38 \\
$\pm 0.01^{\mathrm{c}}$
\end{tabular} \\
\hline Blend 4 & $\begin{array}{l}3.00 \\
\pm 0.01^{\mathrm{c}}\end{array}$ & \begin{tabular}{|l}
2.75 \\
$\pm 0.01^{c}$
\end{tabular} & \begin{tabular}{|l}
2.75 \\
$\pm 0.01^{c}$
\end{tabular} & \begin{tabular}{|l}
2.75 \\
$\pm 0.01 \mathrm{~d}$
\end{tabular} & \begin{tabular}{|l|}
3.00 \\
$\pm 0.01 \mathrm{~d}$
\end{tabular} & \begin{tabular}{|l|}
2.75 \\
$\pm 0.01 \mathrm{~d}$
\end{tabular} & \begin{tabular}{|l|}
2.33 \\
$\pm 0.01 \mathrm{~d}$
\end{tabular} \\
\hline
\end{tabular}

Values are mean and SD $(n=3)$; where: Mean values in the same with the letter are significantly different at 0.05 levels.

\section{Conclusions}

From the obvious results, it could be conclusion that the chia seeds, soybean, and yellow maize had the highest nutritional value and antioxidant activity; meanwhile, psyllium has too high amounts from crude fiber and dietary fiber fractions. Therefore the macaroni which consists of $50 \%$ chia, $r 5 \%$ soybean, 10\% yellow maize, and 5\% psyllium ( blend 3 )was increased in nutrition value and color.

\section{REFERENCES}

AOAC (2010). Official Methods of Analysis of Association of Official Chemists. 18th Ed., Washington, D.C., USA.

Armitage, P. and Berry, G. (1987). Statistical method in medical research. Blackwell, Oxford, UK, pp. 93-213.

Bahnassey, Y. and Khan, K. (1986). Fortification of spaghetti with edible legumes. 11. Rheological, processing and quality evaluation studies, Cereal Chem. 63: 216.

Benzie IFF and Strain JJ (1996). The ferric reducing ability of plasma (FRAP) as a measure of "antioxidant power": The FRAP assay. Analytical Biochemistry 239, 70-76.

Biesiekierski, J.R., Newnham, E.D., Irving, P.M., Barrett, J.S., Haines, M., Doecke, J.D., Shepherd, S.J., Muir, J.G. and Gibson, P.R. (2011). Gluten causes gastrointestinal symptoms in subjects without celiac disease: A doubleblind randomized placebo-controlled trial. Am. J. Gastroenterol. 106, 508-514.

Bilgiçli N, Demir MK, Ertas, N, Herken EN (2011). Effects of gluten and emulsifier on some properties of eriște prepared with legume flours. Int $\mathbf{J}$ Food Sci Nutr 62(1):63-70 
Bordin, A. B. and Roque-Specht, B. (2012). The effects of adding soy fiber to whear spaghetti. Boletim do CEPPA, Curitiba, 30( 2): 177-184.

Williams,B.W.; Cuvelier, M.E. and Berset, C. (1995). Use of a free radical method to evaluate antioxidant activity. LWT - Food Science and Technology, 28: 25-30.

Capitani, M. I.; Spotorno, V.; Nolasco, S. M. and Tomás, M. C. (2012). Physicochemical and functional characterization of by-products from chia (Salvia hispanica L.) seeds of Argentina. LWT. Food Science and Technology, London, 45(1): 94-102.

Capriles, V. D., Santos, F. G., Reis, E. M., Pereira, C. F. (2015). Innovative approaches to improve nutritional and bioactive compounds of grain based gluten-free products. In: Langdon, R. (Ed.), Gluten-free diets:

Food sources, role in celiac disease and health benefits. New York: Nova Science Publishers, Inc, 67-116

Catassi, C. and Yachha, S.K. (2009). The epidemiology of celiac disease. In The Science of Gluten-Free Foods and Beverages (E.K. Arendt and F. Dal Bello, eds.) pp. 1-13.

Chang, Y. and Flores, H. (2004). Qualidade tecnológica de massas alimentícias frescas elaboradas de semolina de trigo durum (T. durum $L$ ) e farinha de trigo (T. aestivum L). Ciência e Tecnologia de Alimentos, Campinas, 24 (4): 487-493.

Chillo, S., Laverse, J., Falcone, P. and Delnobile, M. (2008). Quality spaghetti in base amaranthus whole meal flour added whith quinoa broad bean and chickpea. Journal of Food Engineering, Westport, 84(1): 101-107.

Coelho, MS and de las Mercedes Salas-Mellado M (2015). Effects of substituting chia (Salvia hispanica L.) flour or seeds for wheat flour on the quality of the bread. LWT Food Sci Technol 60(2):729-736

Cureton, P. and Fasano, A. (2009). The increasing incidence of celiac disease and the range of gluten-free products in the marketplace. In Gluten-Free Food Science and Technology (E. Gallagher, ed.) pp. 130-180,Wiley-Blackwell, Oxford, U.K.

Devi K.N., Singh, T.B., Athokpam, H.S., Singh N.B. and Shamurailatpam D. (2013). Influence of inorganic, biological and organic manures on nodulation and yield of soybean ('Glycine max Merril' L.) and soil properties (online). AJCS, 7(9): 1407-1415.

Do Nascimento, A., Fiates, G., dos Anjos, A., \& Teixeira, E. (2013). Analysis of ingredient lists of commercially available gluten-free and glutencontaining food products using the text mining technique. International Journal of Food Sciences and Nutrition, 64, 217-222.

Dexter, J. E., Martin, D. G., Sadaranganey, G. T., Michaelides, J., Mathieson, N., Tkac, J. J. and Marchylo, B. A. (1994). Preprocessing: effects on durum wheat milling and spaghetti-making quality. Cereal Chem.71:10-16.

Eghdami, A. and Sadeghi, F. (2010).Determination of total phenolic and flavonoids contents in methanolic and aqueous extract of Achille amillefolium. Journal of Organic Chemistry, 2, 81-84. 
Fan, J., Wu, Z., Zhao, T., Sun, Y., Ye, H., Xu, R. (2014)."Characterization, antioxidant and hepatoprotective activities of polysaccharides from Ilex latifolia Thunb. Carbohydr Poly,;101:990-7

Francis FJ. (1998). Color analysis. In: Nielsen SS (ed) Food Analysis, Aspen Publishers, New York

Gartaula, G., Dhital, S.; Netzel, G., Flanagan, B.M., Yakubov, G.E., Beahan, C.T.,Collins, H.M., Burton, R.A., Bacic, A., Gidley, M.J. (2018). Quantitative structural organisation model for wheat endosperm cell walls: Celluloseas an important constituent. Carbohydr. Polym., 196, 199-208.

Hrnčič, M.K., Ivanovski , M., Cör, D. and Knez , ž. (2020). Chia Seeds (Salvia Hispanica L.): An overview-Phytochemical Profile, Isolation Methods, and Application, Molecules, 25, 11; 1-19

Hummel, C. (1966). Macaroni products. London: Food Trade Press, 1966. 287. Idris, K.M. (2001). The effect of decortication on wet-milling and starch quality of sorghum and millet grains.M.Sc. Thesis, University of Khartoum, Sudan.

Ixtaina, V. Y., Martínez, M. L., Spotorno, V., Mateo, C. M., Maestri, D. M. and Diehl, B. W. K. (2011). Characterization of chia seed oils obtained by pressing and solvent extraction, J. Food. Comp. Anal. 24(2):166-174.

Jones, J.M. (2014). CODEX-aligned dietary fiber definitions help to bridge the 'fiber gap. Nut. J. 13, 34.

Khampas, S., Lertrat, K., Lomthaisong, K. and Suriharn, B. (2013).

Variability in phytochemicals and antioxidant activity in corn at immaturity and physiological maturity stages, International Food Research Journal 20(6): 3149-3157

Kumar V., Rani A., Solanki S., Hussain S. M. (2006). Influence of growing environment on the biochemical composition and physical characteristics of soybean seed. Journal of Food Composition and Analysis, 19: 188-195

Levent, H. (2017). Effect of partial substitution of gluten-free flour mixtures with chia (Salvia hispanica L.) flour on quality of gluten-free noodles. Journal of Food Science and Technology, 54(7), 1971-1978.

Marineli, R., Moraes, E., Lenquiste, S., Godoy, A., Eberlin, M., \& Marostica, M. (2014). Chemical characterization and antioxidant potential of Chilean chia seeds and oil (Salvia hispanica L.). Lwt-Food Science and Technology, 59, 1304-1310.

Yasin, M.T., Rashid Abdullah, K.A., Qasim Hayat, M., Qazi, N., Niaz Sultan, I., Amanat, K. and Imran Bokhari, SA. (2020). Exploration of the phytochemicals, antimicrobial and antioxidant activities of plantago ovata (ISPAGHOL), INDO American J. Pharmaceutical Sciences, 07 (04), 440-447

Mujić, I., Sertović ,E., Jokić, S., Sarić, Z., Alibabić, V., Vidović, S., Živković, J.(2011). Isoflavone content and antioxidant properties of soybean seeds. Croatian Journal of Food Science and Technology. 3(1):16-20.

Patel , MK., Mishra, A., Jha, B. (2016). Non-targeted metabolite profiling and scavenging activity unveil the nutraceutical potential of Psyllium (Plantago ovata Forsk). Front Plant Sci. 7:431. 
Paulsmeyer, M., Chatham, L., Becker, T., West, M., West, L., Juvik, J.(2017). Survey of anthocyanin composition and concentration in diverse maize germplasms. J. Agric. Food Chem. 65, 4341-4350.

Písař́íková, B. and Zralý, Z. (2010). Dietary Fibre Content in Lupine (Lupinus albus L.)and soya (Glycine max L.) seeds, Acta Vet. Brno .79: 211216.

Porras-Loaiza, P., Jimenez-Munguia, M., Sosa-Morales, M., Palou, E. and Lopez-Malo, A. (2014). Physical properties, chemical characterization and fatty acid composition of Mexican chia (Salvia hispanica L.) seeds. International Journal of Food Science and Technology, 49, 571-577.

Prosky, L., Asp, N. G., Schweizer, T. F., Devries, J. W. and Furdal, I. (1988). Determination of insoluble and soluble and total dietary fiber in food products: Inter laboratory study. J. Assoc. Off. Anal. Chem71: 1017-1023.

Qawasmeh, A., Obied, H. K., Raman, A., \& Wheatley, W. (2012). Influence of fungal endophyte infection on phenolic content and antioxidant activity in grasses: Interaction between Lolium perenne and different strains of Neotyphodiuml olii. Journal of Agricultural and Food Chemistry, 60(13), 33813388.

Re, R., Pellegrini, N., Proteggente, A., Pannala, A., Yang, M. and RiceEvans, C. (1999). Antioxidant activity applying an improved ABTS radical cation decolorization assay. Free Radical Biology \& Medicine, 26: 1231-123

Sargi, S.C.; Silva, B.C.; Santos, H.M.C.; Montanher, P.F.; Boeing, J.S.; Santos, O.O.; Souza, N.E. and Visentainer, J.V. (2013). Antioxidant capacity and chemical composition in seeds rich in omega-3 chia, flax and perilla. Food Sci. Technol, 33, 541-548.

Verma, A. and Mogra, R. (2015). Psyllium (Plantago ovata) Husk: A wonder food for good health, International Journal of Science and Research, 4(9): 1581-1585

Wärnberg, J., Marcos, A., Bueno, G. and Moreno, LA. (2009). Functional benefits of psyllium fiber supplementation, Current Topics in Nutraceutical Research, 7(2), 55-64

William, P.C., Kuzina, F.D. and Hlynka, I. (1975).Rapid colourmetric procedure for estimating the amylose content of starches and flour. Cereal Chem. 4: $411-420$.

Zhao, J. H.; Manthey, F.; Chang, K.; Hou, H.; Yuan, H. (2005). Quality characteristics of spaghetti as affected by green and yellow pea, lentil and chickpea, flours. Journal of Food Science, Chicago, 70( 3): 371-376.

Zandonadi, R.; Botelho, R. and Araújo,W. (2009). Psyllium as a Substitute for gluten in bread. J. Am Diet Assoc. 109: 1781 - 1784.

Žilić, S., Serpen, A., Akıllıŏlu, G., Gökmen, V. and Vančetović, J. (2012). Phenolic compounds, carotenoids, anthocyanins, and antioxidant capacity of colored maize (Zea mays L.) kernels. Agricultural and Food Chemistry 60: 1224-1231. 
Zong, G., Gao, A., Hu, F.B., Sun, Q. (2014). Whole grain intake and mortality from all causes, cardiovascular disease, and cancer a meta-analysis of prospective cohort studies. Circulation, 133, 2370-2380.

\section{ملخص البحث}

تقييم المكرونة الخالية من الجلوتين مع بذور الثيا والقشرة الخارجية للسان الجمل كبديل للجلوتين لأمراض الاضطرابات الهضمية.

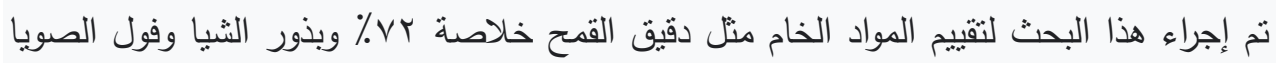

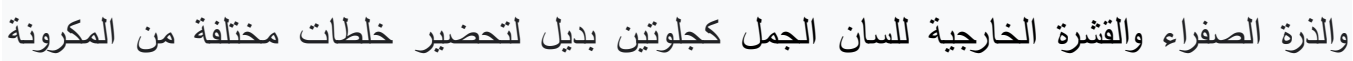
الخالية من الجلوتين لأمراض الاضطرابات الهضمية. نم تحديد التركيب الكيميائي ومحتوى الألياف

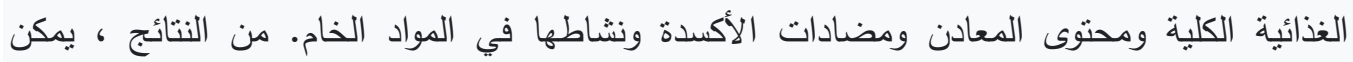

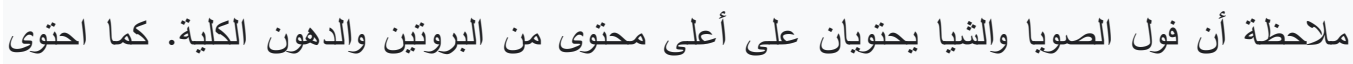

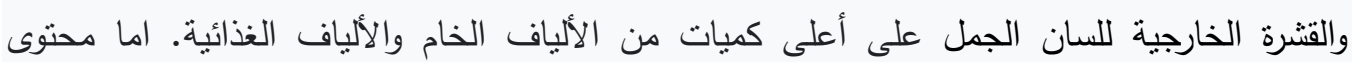

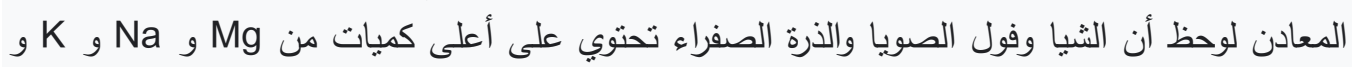

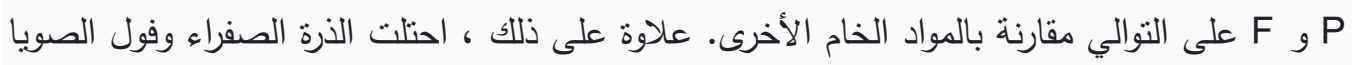
والثيا أعلى محتوى في قدرة ونشاط مضادات الأكسدة.

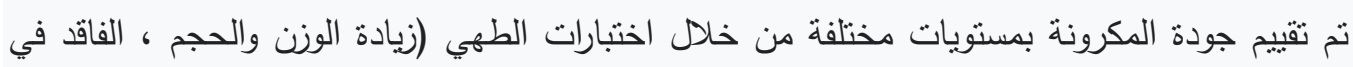

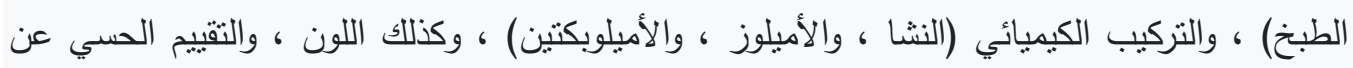

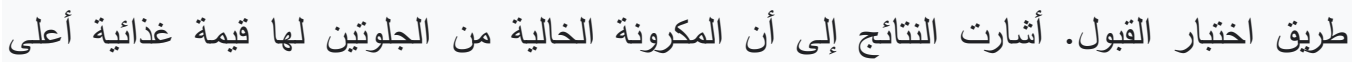

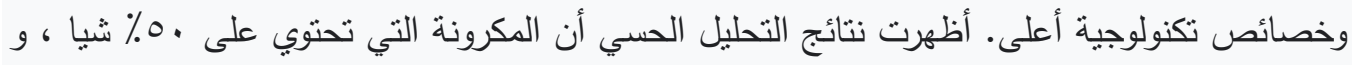

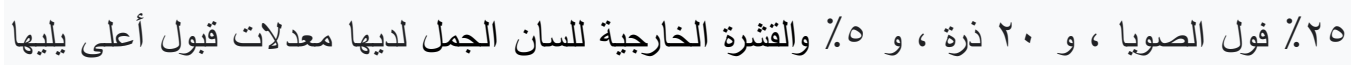

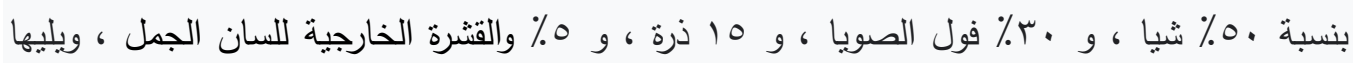

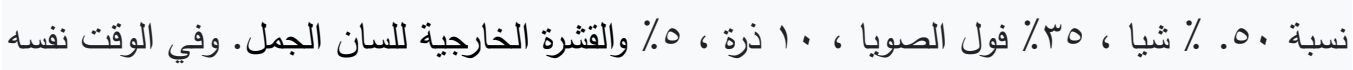

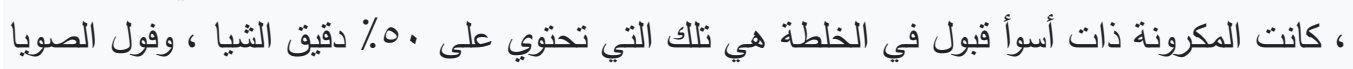

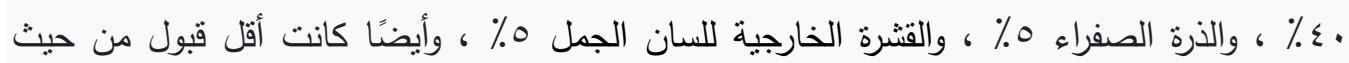
اللون. (- n

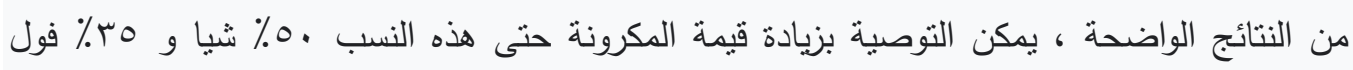
الصويا و 1\% ذرة صفراء و ه\% والقشرة الخارجية للسان الجمل من حيث القيمة الغذائية واللون.

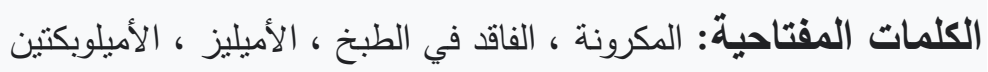

